\title{
Introduction: The Continuing Significance of the Black Panther Party
}

\author{
Judson L. Jeffries ${ }^{1}$
}

Accepted: 29 November 2021 / Published online: 20 December 2021

(c) The Author(s), under exclusive licence to Springer Science+Business Media, LLC, part of Springer Nature 2021

In honor of the 55th anniversary of the founding of the Black Panther Party, we here at the Journal of African American Studies decided to mark the occasion with this mini-symposium, consisting of three articles and a book review. Founded in 1966, in response to police harassment, brutality, and murder of Bay Area residents, namely, African Americans, the Party quickly evolved over the next few years, compelling it to establish a number of Community Survival Programs in order to address many of the same issues that plague Black communities in 2021. Issues such as the miseducation of not only Black people, but Americans generally, malnourishment, and access to health care, to name a few. People of color as well as poor people are, in many ways, not significantly better off today than they were when the Black Panther Party was in its heyday.

Given the indiscriminate murder of Blacks by white police officers with impunity and the disproportionate number of Black deaths, resulting from COVID-19, one could argue that at no time since its demise has this generation of African Americans been more in need of its own Black Panther Party, a more modern version, of course. There is no systematic data that shows how impactful the Panthers' patrols of the police were in the Bay Area, but anecdotal evidence, including personal testimonies, suggests that their monitoring of the police was not inconsequential. When they weren't patrolling their neighborhoods, they were pushing for civilian review boards as a way of holding police departments accountable and calling for a policy requiring that law enforcement officers be residents of the communities they were charged with policing. And what would party members be doing, in 2021, in this time of pandemic? Most likely going door-to-door administering COVID-19 tests or setting up testing stations at outdoor shopping malls or outdoor festivals or nearby grocery stores. In other words, much the same way, they tested residents for tuberculosis and sickle-cell anemia, two diseases from which Blacks suffered disproportionately. Needless to say, residents' health and well-being, regardless of the person's socio-economic status was something that the Panthers took seriously. The Panthers'

Judson L. Jeffries

jeffries.70@osu.edu

1 Department of African American and African Studies, The Ohio State University, Columbus, OH 43210, USA 
free medical clinics, that thrived in-but were not limited to-cities such as Oakland, Boston, Seattle, and Portland would be a welcome sight today and a muchneeded resource in many Black communities. There was no insurance necessary, no being inundated with paperwork, and no hassle. Anyone who was in need, was taken care of.

The Black Panther Party and its Community Survival Programs are no less significant today than was the case more than 50 years ago. Survival pending revolution is what the Panthers were fond of saying. And while the Party's Community Survival Programs are not featured in the works below, this mini-symposium is in recognition of the Panthers' continuing importance.

Publisher's Note Springer Nature remains neutral with regard to jurisdictional claims in published maps and institutional affiliations. 